\title{
Identification and Evaluation of the Prevalent Practices of Prescribers while Prescribing Antibiotics in Infants
}

\author{
Syed Ali Sibtain ${ }^{1}$, Sohail Manzoor ${ }^{2 *}$, Uzma Mazhar' ${ }^{1}$, Muhammad Ali ${ }^{3}$, Imtiaz Ahmad Khan ${ }^{4}$, Fraz Munir Khan ${ }^{5}$, \\ Syed Abbas Ali ${ }^{5}$ and Mushtaqu Ahmad Gondal ${ }^{5}$
}

${ }^{1}$ Department of Pharmacy, University of Sargodha, Pakistan

${ }^{2}$ Disease Diagnostic Laboratories, Division Multan, Pakistan

${ }^{3}$ Faculty of Pharmacy, University of Punjab, Pakistan

${ }^{4}$ Faculty of Veterinary Science, Department of Pathobiology, Arid Agriculture University, Rawalpindi, Pakistan

${ }^{5}$ Provincial Diagnostic Laboratory, Pakistan

Submission: March 14, 2017; Published: April 12, 2017

*Corresponding authors: Sohail Manzoor, Disease Diagnostic Laboratories, Division Multan, Pakistan, Tel: 92-333-6503982;

Email: manzoorsohail76@gmail.com

\begin{abstract}
With a handsome sample, specialists, general practitioners and Quacks both male and female from Faisalabad district of the province of Punjab, Pakistan, were approached for the study. A self-administered questionnaire was designed for the purpose. Factors to prescribe an antibiotic and the reasons for the attitude to prescribe a broad-spectrum antibiotic were elicited. Suggestions regarding prudent use of antibiotics were also collected from the prescribers. According to the answers, the prescribers of City Area are more rational as compared to the Semi-Urban or Rural Area in all the specialties including, Infants, Pregnant/Lactating Mothers, Hepatic and Renal Impairment. This is perhaps due to lack of fresh knowledge and less experience in the respective field. On the other hand, as we go from highly educated prescribers to less qualified doctors or Non-doctors (Quacks), the use of antibiotic become less rational or irrational. It is obvious from the results that the use of antibiotics is irrational or less rational. It also means that antibiotics are misused by the prescribers, which results in the antibiotic resistant emergence of bacterial strains. So, the antibiotic use must be in accordance with the current guidelines by the leading health providing institutions. However, the highly qualified doctors are using antibiotics more rationally as compared to less qualified doctors or non- doctors eg., quacks and LHVs.
\end{abstract}

Keywords: Quacks; Infants; Antibiotics; Infectious diseases

\section{Introduction}

Antibiotics are natural or synthetic substances that have ability either to destroy micro-organisms or to inhibit their growth. Antibiotics are extensively used to treat infectious diseases of humans, plants and animals [1].

While prescribing antibiotics, factors related to the patient which must be considered include history of allergy, renal and hepatic function, susceptibility to infection (i.e. whether immune-compromised), ability to tolerate drugs by mouth, severity of illness, ethnic origin, age, whether taking other medication and, if female, whether pregnant, breast-feeding or taking an oral contraceptive, renal and hepatic impairment. The known or likely organism and its antibacterial sensitivity, in association with the above factors, will suggest one or more antibiotics; the final choice is made depending on the microbiological, pharmacological, and toxicological properties of that / those antibiotic(s) [2].

The antibiotics when prescribed to the above mentioned criteria can say that they are used appropriately or rationally. Buetow defined appropriateness as "The outcome of a process of decision making that emphasizes/maximizes net individual health gains within society's available resources". It means, appropriateness is the outcome when the patient receives the "right" drug, regardless the grounds on which the prescribing decision is based. The outcome here means the immediate outcome of the prescribing decision, i.e. the prescription, rather than longer-term outcomes for the patient [3].

Emergence of drug-resistant pathogens is a growing issue to world's population regardless of age, gender, or socioeconomic 
background. They endanger people not only in industrial societies like the United States, United Kingdom and other developed countries but in less developed nations as well [4].

Okeke et al. [5] depicted that there are multiple factors contributing to resistance problem in developing countries around the world.

\section{These factors include:}

o Chaotic and widespread use of antimicrobials for community-acquired infections,

o Self-medication [5]

o Over the counter availability of antibiotics [7]

In developing countries the situation of drug irrational use is particularly alarming. In Pakistan, the average number of drugs per prescription was 3.5; with antibiotics accounting for $76 \%$ of the prescribed drugs [8].

For this reason purpose of this study was to identify and evaluate factors influencing prevalent attitudes and practices of prescribers regarding antibiotic usage in Infants.

\section{Materials and Methods}

The questionnaire was designed keeping in view all these specialties regarding the antibiotic use by the prescribers. After getting the data by providing a self-administered, anonymous questionnaire to the health care providers, it was divided into two striatums;

o Area

\section{o Qualification}

In all the studies, questions from basically two aspects were asked from the participants;

o General Knowledge about the Antibiotic use in the respective field

o Situations where broad spectrum antibiotics are being used instead of narrow spectrum antibiotics

Another aspect which was kept in mind while designing questionnaire is that if the answer of a question is Yes or No, it will be rational or irrational depending on the type of question. In Infants questionnaire, the antibiotic use will be rational if the answer of the following questions is 'Yes'

o Do you agree with the opinion that in infants none of the antibiotic would be safest one?

o Do you think that Kernicterus is an important consideration while prescribing antibiotic in infants?

o To treat the infections in infants, a best approach is to use a narrow spectrum antibiotic with highest efficacy

o According to your opinion, in infants, use of antibiotics having wide therapeutic index should be encouraged o Do you agree that culture and sensitivity report must be done before using antibiotics in infants?

o Do you agree that the development of antibiogram can be helpful to use antibiotics prudently in infants?

And the antibiotic use will be rational if the answer of the following questions is 'No'

o Do you think that sulphonamides (Trimethoprim, Sulfamethoxazole etc.) are the safest drugs to treat UTI in infants?

o In infants would you prefer tetracyclines as a group of broad spectrum antibiotics?

o Do you agree with the opinion that amino glycosides are the drugs of choice in infants?

o To treat the infections in infants, a best approach is to use a broad spectrum antibiotic with highest efficacy

o Usually Fluoroquinolones are used to treat LRTI in infants. Should their use be strongly recommended?

o Do you agree with the opinion that the use of more than one narrow spectrum antibiotics would be preferred over a single broad spectrum antibiotic?

The survey was done with a self-designed questionnaire eliciting the factors influencing the decision of the prescribers while prescribing antimicrobials. The participants included Non-Specialists, e.g. General Practitioners (having MBBS degree), quacks, Lady Health Visitors (LHVs) and Specialists, e.g Medical, surgical, obstetrics/gynecology, pediatricsetc having postgraduate degrees or diplomas in their field). The survey was carried out in Faisalabad districts, of the Province of Punjab, Pakistan (8 towns, both urban and semi-urban areas) and rural areas adjoining the Faisalabad). The whole city is covered by about 2500 registered medical practitioners. The study was conducted from September 2009 to September 2010. The sampling of the participants was a simple and determined by approaching the participants individually and requested them to answer the questionnaire. The study was approved by the Board of Scientific Studies, University of Sargodha, Sargodha. The questionnaire used, was the modified version of that used by the Alliance for the Prudent Use of Antibiotics in cooperation with the Massachusetts Infectious Disease Society and the Massachusetts Department of Public Health.

Questions in the questionnaire are basically designed keeping in view the factors which can help in deriving the results at the end of the study. It contains basic details like specialty based questions about the usage of antibiotics in Infants. Also include factors like (Educational status, and Area of practice place), questions pertaining to the factors involved in the decision making to prescribe an antibiotic (like fever, purulent discharge, patient request, colleague's opinion etc) and factors responsible for the attitude to prescribe a broad-spectrum 
antibiotic while a narrow spectrum would suffice. Apart from that, the three most common infections practitioners often treat, the three most common antibiotics they prescribe, and the conditions in which they use the antibiogram facility were also elicited. Finally, they were asked to give suggestions on ways and means to use antibiotics prudently in specialties like Infants.

Besides this, main factors which kept into focus while making the questionnaire in general were (Table 1):

Table 1: Main factors which kept into focus while making the questionnaire.

\begin{tabular}{|c|c|}
\hline S.No. & Factors \\
\hline 1 & Peer suggestion \\
\hline 2 & Formulary of the hospital \\
\hline 3 & Promotion by Sales Representative \\
\hline 4 & Litigation Concern \\
\hline 5 & Fever \\
\hline 6 & Chills \\
\hline 7 & Purulent Discharge \\
\hline 8 & Visit cost \\
\hline 9 & Medication cost \\
\hline 10 & Patient satisfaction \\
\hline 11 & Time pressure \\
\hline 12 & Culture report \\
\hline 13 & Diagnostic uncertainty \\
\hline 14 & Patient request \\
\hline 15 & Age \\
\hline 16 & \\
\hline
\end{tabular}

Other factors, where broad spectrum antibiotic is used instead of narrow spectrum were as follows (Table 2):

Table 2: Broad spectrum antibiotics.

\begin{tabular}{|c|c|}
\hline S.No. & Factors \\
\hline 1 & Peer suggestion \\
\hline 2 & Formulary of the hospital \\
\hline 3 & Promotion by Sales Representative \\
\hline 4 & Litigation Concern \\
\hline 5 & Fever \\
\hline 6 & Chills \\
\hline 7 & Purulent Discharge \\
\hline 8 & Antibiotic resistance concern \\
\hline 9 & Visit cost \\
\hline 10 & Medication cost \\
\hline 11 & Patient satisfaction \\
\hline 12 & Time pressure \\
\hline 13 & Treatment uncertainty \\
\hline 14 & Diagnostic uncertainty \\
\hline 15 & Patient request \\
\hline 16 & Age \\
\hline
\end{tabular}

The language of the questionnaire was English, and the time for answering it was approx 30 minutes. All the data were entered in a Microsoft Excel spreadsheet and rechecked by 2 independent persons for any errors.

There are four major groups upon which questionnaire were formulated to carry out the study. While making the questionnaire, questions were designed such that, if the answer of a particular question is Yes/No, it will be considered rational or irrational depending on the type of the question. The questionnaires are as follows:

\section{Questionnaire regarding infants to be asked from prescribers}

NAME:

DESIGNATION:

GENDER:

PROFESSION:

QUALIFICATION:

SPECIALITY:

DESIGNATION:

INSTITUTION:

WORKING ADDRESS:

PHONE:.

CELL:

EMAIL:

Table 3

Table 3: Questionnaire regarding infants to be asked from prescribers.

\begin{tabular}{|c|c|c|c|c|}
\hline S.No & Question & Yes & No & Don't Know \\
\hline 1 & $\begin{array}{l}\text { Do you agree with the opinion } \\
\text { that in infants none of the } \\
\text { antibiotic would be safest one? }\end{array}$ & & & \\
\hline 2 & $\begin{array}{l}\text { Do you think that sulphonamides } \\
\text { (Trimethoprim, Sulfamethoxazole } \\
\text { etc.) are the safest drugs to treat } \\
\text { UTI in infants? }\end{array}$ & & & \\
\hline 3 & $\begin{array}{l}\text { Do you think that Kernicterus is } \\
\text { an important consideration while } \\
\text { prescribing antibiotic in infants? }\end{array}$ & & & \\
\hline 4 & $\begin{array}{l}\text { In infants would you prefer } \\
\text { tetracyclines as a group of broad } \\
\text { spectrum antibiotics? }\end{array}$ & & & \\
\hline 5 & $\begin{array}{l}\text { Do you agree with the opinion } \\
\text { that amino glycosides are the } \\
\text { drugs of choice in infants? }\end{array}$ & & & \\
\hline 6 & $\begin{array}{l}\text { To treat the infections in infants, } \\
\text { a best approach is to use a broad } \\
\text { spectrum antibiotic with highest } \\
\text { efficacy. }\end{array}$ & & & \\
\hline
\end{tabular}




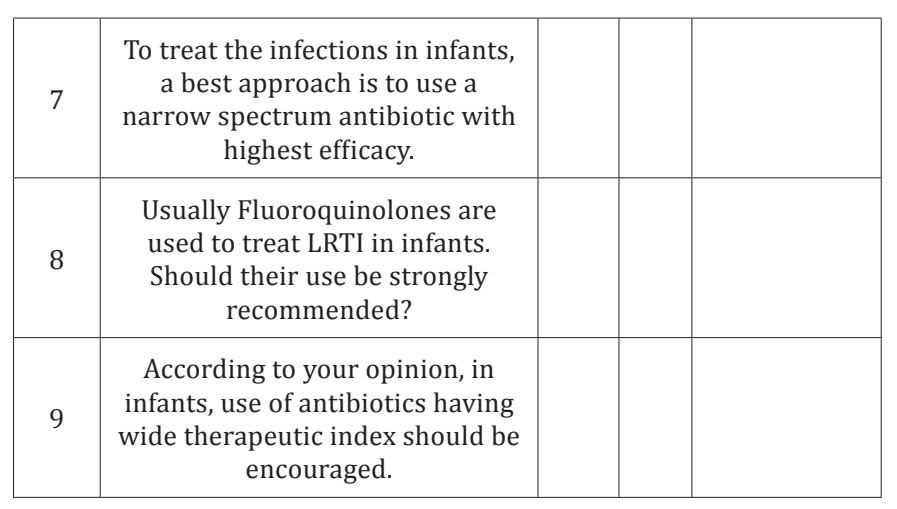

\begin{tabular}{|c|c|l|l|l|}
\hline 10 & $\begin{array}{c}\text { Do you agree that culture and } \\
\text { sensitivity report must be done } \\
\text { before using antibiotics in } \\
\text { infants? }\end{array}$ & & & \\
\hline 11 & $\begin{array}{c}\text { Do you agree that the } \\
\text { development of antibiogram } \\
\text { can be helpful to use antibiotics } \\
\text { prudently in infants? }\end{array}$ & $\begin{array}{c}\text { Do you agree with the opinion } \\
\text { that the use of more than one } \\
\text { narrow spectrum antibiotics } \\
\text { would be preferred over a single } \\
\text { broad spectrum antibiotic? }\end{array}$ & &
\end{tabular}

\section{Factors in the selection of a broad spectrum antibiotic while a narrow spectrum can be used in infants?}

Table 4

Table 4: Factors in the selection of a broad spectrum antibiotic while a narrow spectrum can be used in infants?

\begin{tabular}{|c|c|c|c|c|}
\hline S.No. & Question & Strongly agreed & Moderately agreed & Disagreed \\
\hline 1 & $\begin{array}{l}\text { Does the patient satisfaction an important factor in the selection of a } \\
\text { broad spectrum antibiotic while a narrow spectrum can be used? }\end{array}$ & & & \\
\hline 2 & $\begin{array}{l}\text { Does lack of true diagnosis play an important role in the selection } \\
\text { of a broad spectrum antibiotic while a narrow spectrum antibiotic } \\
\text { would be an option? }\end{array}$ & & & \\
\hline 3 & $\begin{array}{l}\text { Age of the patient is a key factor in the selection of a broad spectrum } \\
\text { antibiotic while a narrow spectrum antibiotic would be suffices? }\end{array}$ & & & \\
\hline 4 & $\begin{array}{l}\text { Does patient request influence you to prescribe a broad spectrum } \\
\text { antibiotic while a narrow spectrum can be an option? }\end{array}$ & & & \\
\hline 5 & $\begin{array}{l}\text { Do you consider your colleagues opinion while prescribing a broad } \\
\text { spectrum antibiotic instead of using a narrow spectrum antibiotic? }\end{array}$ & & & \\
\hline 6 & $\begin{array}{l}\text { Do you consider that antibiotic resistance is a major influential factor } \\
\text { in the selection of a broad spectrum antibiotic? }\end{array}$ & & & \\
\hline
\end{tabular}

i. 1-Please share with us about three most common infections prevalent in infants?

ii. Please share three most frequently used antibiotics in infants?

$+2$

Below is the Performa which is used to represent the collected data in the form of excel sheet on the basis of Yes, No iii. Which formula is considered best to calculate the dose of an antibiotic in infants?

iv. Please share your experience and tell us which broad spectrum antibiotic you think is safest in infants?

and Don't Know in Infants (On the Basis of Area based Striatum) (Table 5 \& 6). 
Table 5: Collected data On the Basis of Area based Striatum in infants.

\begin{tabular}{|c|c|c|c|c|c|c|c|}
\hline \multicolumn{8}{|c|}{ STRIATUM \# 1 GROUP \# 1 ON THE BASIS OF PRACTICE PLACE } \\
\hline \multicolumn{4}{|c|}{ Prescribers of City Area Approached } & \multicolumn{4}{|c|}{ Prescribers of Semi-urban or rural Area Approached } \\
\hline \multicolumn{4}{|c|}{ Prescribers of City Area Responded } & \multicolumn{4}{|c|}{ Prescribers of Semi-urban or rural Area Approached } \\
\hline \multirow{2}{*}{ S. NO } & \multicolumn{3}{|c|}{ Prescribers of City Area } & \multicolumn{3}{|c|}{ Prescribers of Semi Urban or Rural Areas } & \multirow{11}{*}{ Infants } \\
\hline & Yes & No & Don't know & Yes & No & Don't know & \\
\hline 1 & & & & & & & \\
\hline 2 & & & & & & & \\
\hline 3 & & & & & & & \\
\hline 4 & & & & & & & \\
\hline 5 & & & & & & & \\
\hline 6 & & & & & & & \\
\hline 7 & & & & & & & \\
\hline 8 & & & & & & & \\
\hline 9 & & & & & & & \\
\hline
\end{tabular}

Table 6: On the basis of strongly agreed, moderately agreed and disagreed.

\begin{tabular}{|c|c|c|c|c|c|c|c|}
\hline \multicolumn{8}{|c|}{ STRIATUM \# 1 GROUP \# 2 ON THE BASIS OF PRACTICE PLACE } \\
\hline \multicolumn{4}{|c|}{ Prescribers of City Area Approached } & \multicolumn{4}{|c|}{ Prescribers of Semi-urban or rural Area Approached } \\
\hline \multicolumn{4}{|c|}{ Prescribers of City Area Responded } & \multicolumn{4}{|c|}{ Prescribers of Semi-urban or rural Area Approached } \\
\hline \multirow{2}{*}{ S. NO } & \multicolumn{3}{|c|}{ Prescribers of City Area } & \multicolumn{3}{|c|}{ Prescribers of Semi Urban or Rural Areas } & \multirow{8}{*}{ Infants } \\
\hline & $\begin{array}{l}\text { Strongly } \\
\text { Agreed }\end{array}$ & $\begin{array}{c}\text { Moderately } \\
\text { Agreed }\end{array}$ & Disagreed & $\begin{array}{l}\text { Strongly } \\
\text { Agreed }\end{array}$ & $\begin{array}{c}\text { Moderately } \\
\text { Agreed }\end{array}$ & Disagreed & \\
\hline 1 & & & & & & & \\
\hline 2 & & & & & & & \\
\hline 3 & & & & & & & \\
\hline 4 & & & & & & & \\
\hline 5 & & & & & & & \\
\hline 6 & & & & & & & \\
\hline
\end{tabular}


Below is the Performa which is used to represent the collected data in the form of excel sheet on the basis of Strongly

Table 7: On the Basis of Qualification based Striatum.
Agreed, Moderately Agreed and Disagreed (On the Basis of Area based Striatum) (Table 7).

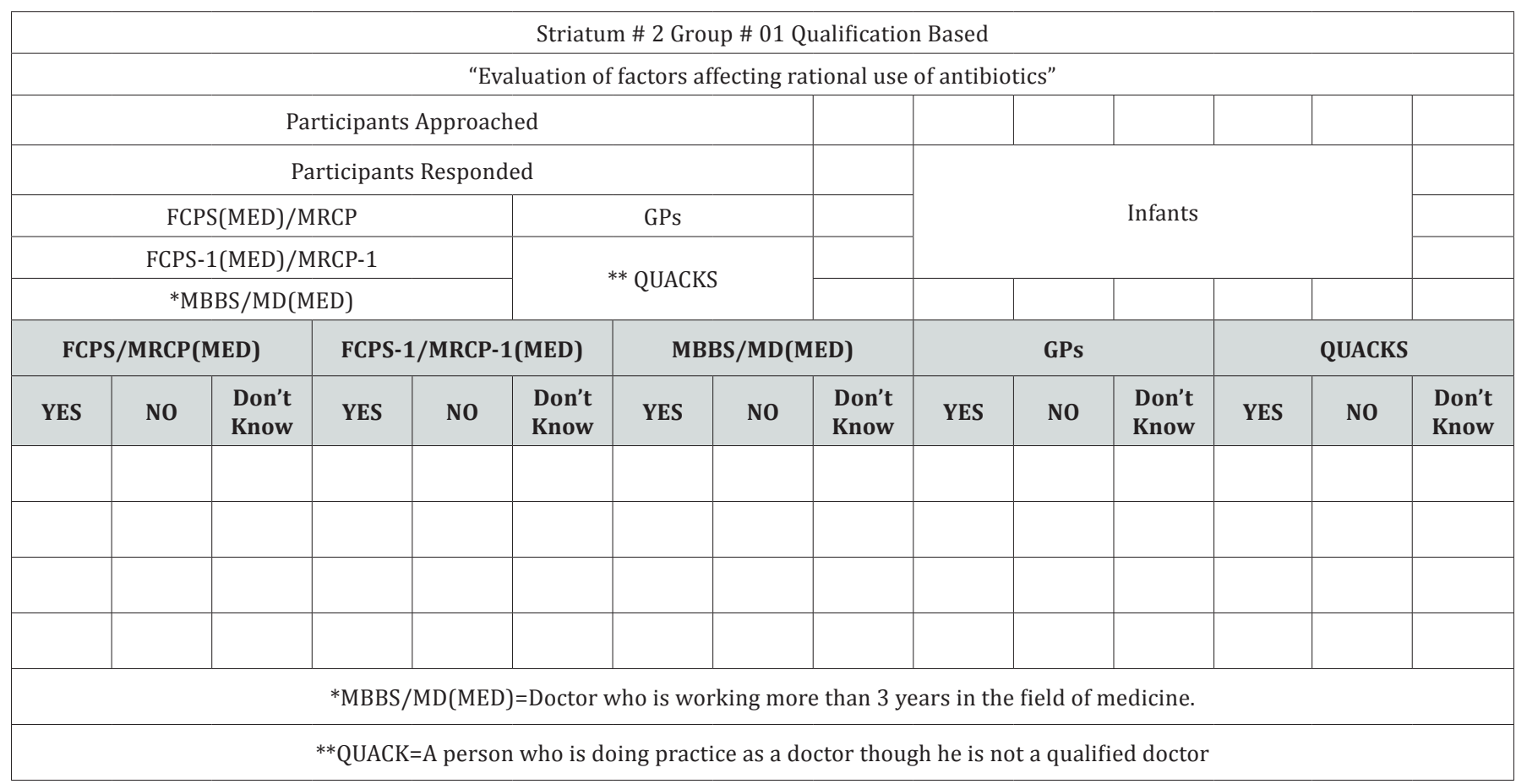

Below is the Performa which is used to represent the collected data in the form of excel sheet on the basis of Yes, No and Don't Know in Infants (On the Basis of Qualification based Striatum) (Table 8).

Below is the Performa which is used to represent the collected data in the form of excel sheet on the basis of Strongly Agreed, Moderately Agreed and Disagreed (On the Basis of Qualification based Striatum) (Table 9).

\section{Results}

\section{Area based striatum (Group 1)}

Total 149 participants were approached, out of which 85 answered the questionnaire. These responders are divided into two sectors on the basis of the area i.e.,

o $\quad$ City or Urban Area

o Semi-urban or rural Area

The participation ratio according to the Area based group was $74 \%$ and $45 \%$ respectively. From the City or Urban group $25.67 \%$ participants answered the 12 questions in whole as "Yes", 13.42\% answered as "No" and 5.92\% answered "Don't Know".

From Semi-urban or Rural area group 20.5\% participants answered the 12 questions in whole as "Yes", 13.75\% answered as "No" and 5.75\% answered "Don't Know" (Table 10).

\section{Area based striatum (Group 2)}

From the City or Urban group 26.33\% participants "Strongly Agreed", 12.17\% "Moderately agreed" and 6.50\% "Disagreed" with the Question No. 1 to 6.

From Semi-urban or Rural area group $25.17 \%$ participants "Strongly Agreed", 7.50\% "Moderately agreed" and 7.33\% "Disagreed" with the Question No. 1 to 6 (Table 11).

\section{Qualification based striatum (Group 1)}

Total 149 participants were approached, out of which 85 answered the questionnaire. On the basis of qualification, this data is divided into different groups:
a. $\quad \mathrm{FCPS}(\mathrm{MED}) / \mathrm{MRCP}=3$
b. FCPS-1(MED)/MRCP-1 =7
c. $*$ MBBS $/ \mathrm{MD}(\mathrm{MED})=35$
d. GPs $=15$
e. $\quad * *$ QUACKS $=25$

The participation ratio according to the Qualification based group was $04 \%, 08 \%, 41 \%, 18 \%$ and $29 \%$ respectively.

From the $1^{\text {st }}$ group $1.92 \%$ participants answered the 12 questions in whole as "Yes", 1.08\% answered as "No" and 0\% answered "Don't Know".

From the $2^{\text {nd }}$ group $3.92 \%$ participants answered the 12 questions in whole as "Yes", 2.58\% answered as "No" and $0.50 \%$ answered "Don't Know". 
Table 8: Collected data in the form of excel sheet on the basis of Strongly Agreed, Moderately Agreed and Disagreed (On the Basis of Qualification based Striatum.

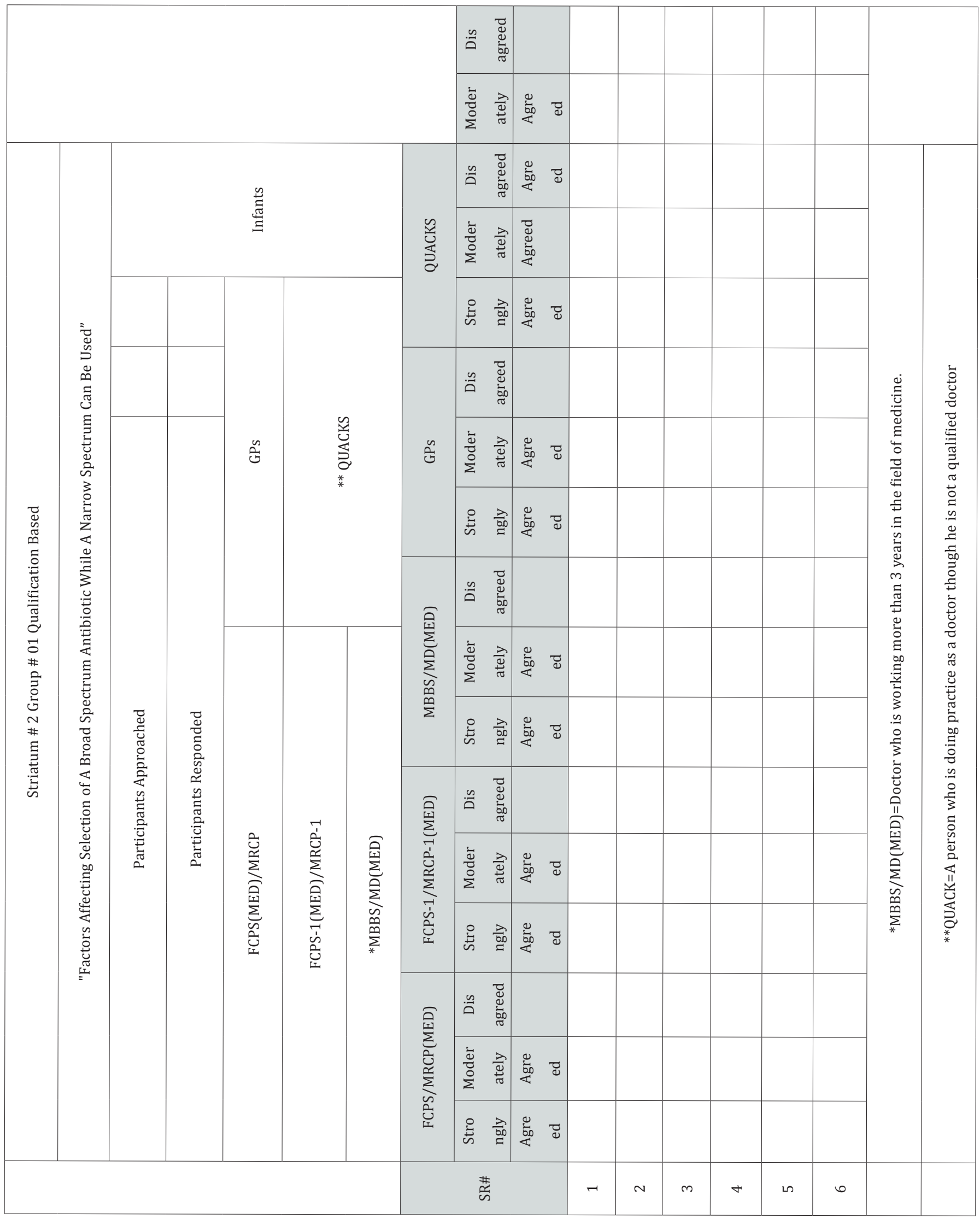


Table 9: Area Based Striatum (Group \# 1).

\begin{tabular}{|c|c|c|c|c|c|c|c|}
\hline \multicolumn{8}{|c|}{ Striatum \# 1 Group \# 1 On The Basis of Practice Place } \\
\hline \multicolumn{4}{|c|}{ Prescribers of City Area Approached \# 61} & \multicolumn{4}{|c|}{ Prescribers of Semi-urban or rural Area Approached \# 88} \\
\hline \multicolumn{4}{|c|}{ Prescribers of City Area Responded \# 45} & \multicolumn{4}{|c|}{ Prescribers of Semi-urban or rural Area Approached \# 40} \\
\hline \multirow{2}{*}{ S.No } & \multicolumn{3}{|c|}{ Prescribers of City Area } & \multicolumn{3}{|c|}{ Prescribers of Semi Urban or Rural Areas } & \multirow{14}{*}{ Infants } \\
\hline & Yes & No & Don't know & Yes & No & Don't know & \\
\hline 1 & 26 & 8 & 11 & 22 & 10 & 8 & \\
\hline 2 & 16 & 25 & 4 & 16 & 16 & 8 & \\
\hline 3 & 36 & 6 & 3 & 27 & 8 & 5 & \\
\hline 4 & 0 & 41 & 4 & 18 & 19 & 3 & \\
\hline 5 & 31 & 11 & 3 & 27 & 9 & 4 & \\
\hline 6 & 32 & 8 & 5 & 25 & 10 & 5 & \\
\hline 7 & 18 & 19 & 8 & 12 & 20 & 8 & \\
\hline 8 & 28 & 4 & 13 & 18 & 14 & 8 & \\
\hline 9 & 40 & 2 & 3 & 30 & 6 & 4 & \\
\hline 10 & 34 & 7 & 4 & 24 & 14 & 2 & \\
\hline 11 & 25 & 10 & 10 & 14 & 20 & 6 & \\
\hline 12 & 22 & 20 & 3 & 13 & 19 & 8 & \\
\hline
\end{tabular}

Table 10: Area Based Striatum (Group \# 2).

\begin{tabular}{|c|c|c|c|c|c|c|c|}
\hline \multicolumn{8}{|c|}{ Striatum \# 1 Group \# 2 On the Basis of Practice Place } \\
\hline \multicolumn{4}{|c|}{ Prescribers of City Area Approached \# 61} & \multicolumn{4}{|c|}{ Prescribers of Semi-urban or rural Area Approached \# 88} \\
\hline \multicolumn{4}{|c|}{ Prescribers of City Area Responded \# 45} & \multicolumn{4}{|c|}{ Prescribers of Semi-urban or rural Area Approached \# 40} \\
\hline \multirow{2}{*}{ S.No } & \multicolumn{3}{|c|}{ Prescribers of city Area } & \multicolumn{3}{|c|}{ Prescribers of Semi-urban or Rural Area } & \multirow{8}{*}{ Infants } \\
\hline & Strongly & Moderately & Disagreed & Strongly & Moderately & Disagreed & \\
\hline 1 & 19 & 19 & 7 & 26 & 8 & 6 & \\
\hline 2 & 40 & 1 & 4 & 31 & 2 & 7 & \\
\hline 3 & 23 & 12 & 10 & 15 & 15 & 10 & \\
\hline 4 & 18 & 22 & 5 & 25 & 8 & 7 & \\
\hline 5 & 24 & 16 & 5 & 24 & 9 & 7 & \\
\hline 6 & 34 & 3 & 8 & 30 & 3 & 7 & \\
\hline
\end{tabular}


Table 11: Qualification Based Striatum (Group 1).

\begin{tabular}{|c|c|c|c|c|c|c|c|c|c|c|c|c|c|c|c|}
\hline & \multicolumn{15}{|c|}{ Striatum \# 2 Group \# 01 Qualification Based } \\
\hline & \multicolumn{15}{|c|}{ "Evaluation of Factors Affecting Rational Use of Antibiotics" } \\
\hline & \multicolumn{7}{|c|}{ Participants Approached=149 } & & & & & & & & \\
\hline & \multicolumn{7}{|c|}{ Participants Responded=85 } & & & & & \multirow{4}{*}{\multicolumn{3}{|c|}{ Infants }} & \\
\hline & & FCPS & (ED)/MP & $P=3$ & & & $\mathrm{GPs}=1$ & & & & & & & & \\
\hline & & CPS-1 & (ED)/MP & $\mathrm{P}-1=7$ & & \multirow{2}{*}{\multicolumn{3}{|c|}{ ** QUACKS=25 }} & & & & & & & \\
\hline & & ${ }^{*} \mathrm{MB}$ & /MD(ME & $=35$ & & & & & & & & & & & \\
\hline \multirow[b]{2}{*}{ SR\# } & \multicolumn{3}{|c|}{ FCPS/MRCP(MED) } & \multicolumn{3}{|c|}{ FCPS-1/MRCP-1(MED) } & \multicolumn{3}{|c|}{ MBBS/MD(MED) } & \multicolumn{3}{|c|}{ GPs } & \multicolumn{3}{|c|}{ Quacks } \\
\hline & YES & NO & $\begin{array}{l}\text { Don't } \\
\text { Know }\end{array}$ & YES & NO & $\begin{array}{l}\text { Don't } \\
\text { Know }\end{array}$ & YES & No & $\begin{array}{l}\text { Don't } \\
\text { Know }\end{array}$ & YES & NO & $\begin{array}{l}\text { Don't } \\
\text { Know }\end{array}$ & YES & No & $\begin{array}{l}\text { Don't } \\
\text { Know }\end{array}$ \\
\hline 1 & 3 & 0 & 0 & 6 & 0 & 1 & 17 & 8 & 10 & 7 & 4 & 4 & 12 & 7 & 6 \\
\hline 2 & 0 & 3 & 0 & 0 & 7 & 0 & 16 & 15 & 4 & 6 & 6 & 3 & 8 & 12 & 5 \\
\hline 3 & 3 & 0 & 0 & 7 & 0 & 0 & 26 & 6 & 3 & 9 & 4 & 2 & 11 & 6 & 8 \\
\hline 4 & 0 & 3 & 0 & 0 & 7 & 0 & 0 & 31 & 4 & 0 & 14 & 1 & 5 & 15 & 5 \\
\hline 5 & 1 & 2 & 0 & 0 & 7 & 0 & 28 & 4 & 3 & 12 & 1 & 2 & 14 & 10 & 1 \\
\hline 6 & 1 & 2 & 0 & 5 & 1 & 1 & 26 & 6 & 3 & 10 & 2 & 3 & 12 & 10 & 3 \\
\hline 7 & 3 & 0 & 0 & 5 & 2 & 0 & 10 & 17 & 8 & 5 & 8 & 2 & 10 & 12 & 3 \\
\hline 8 & 3 & 0 & 0 & 4 & 0 & 3 & 21 & 4 & 10 & 8 & 3 & 4 & 13 & 10 & 2 \\
\hline 9 & 3 & 0 & 0 & 7 & 0 & 0 & 31 & 1 & 3 & 12 & 1 & 2 & 14 & 10 & 1 \\
\hline 10 & 2 & 1 & 0 & 6 & 1 & 0 & 26 & 5 & 4 & 10 & 4 & 1 & 10 & 11 & 4 \\
\hline 11 & 3 & 0 & 0 & 6 & 0 & 1 & 16 & 10 & 9 & 5 & 8 & 2 & 8 & 10 & 7 \\
\hline \multirow[t]{3}{*}{12} & 1 & 2 & 0 & 1 & 6 & 0 & 20 & 12 & 3 & 5 & 8 & 2 & 10 & 9 & 6 \\
\hline & \multicolumn{15}{|c|}{${ }^{*}$ MBBS/MD(MED)=Doctor who is working more than 3 years in the field of medicine. } \\
\hline & \multicolumn{15}{|c|}{${ }^{* *} \mathrm{QUACK}=\mathrm{A}$ person who is doing practice as a doctor though he is not a qualified doctor } \\
\hline
\end{tabular}

Table 12: Qualification Based Striatum (Group 2).

\begin{tabular}{|c|c|c|c|c|c|c|c|c|c|c|c|c|c|c|}
\hline \multicolumn{15}{|c|}{ Striatum \# 2 Group \# 02 Qualification Based } \\
\hline \multicolumn{15}{|c|}{ "Factors Affecting Selection of A Broad Spectrum Antibiotic While } \\
\hline \multicolumn{9}{|c|}{ Participants Approached=149 } & \multirow{2}{*}{\multicolumn{6}{|c|}{ Infants }} \\
\hline \multicolumn{9}{|c|}{ Participants Responded= 85} & & & & & & \\
\hline \multicolumn{8}{|c|}{ FCPS(MED) $/ \mathrm{MRCP}=3$} & GPs $=15$ & & & & & & \\
\hline \multicolumn{8}{|c|}{ FCPS-1(MED)/MRCP-1 =7 } & \multirow{2}{*}{ ** Quack s=25 } & & & & & & \\
\hline \multicolumn{8}{|c|}{$* \mathrm{MBBS} / \mathrm{MD}(\mathrm{MED})=35$} & & & & & & & \\
\hline \multicolumn{3}{|c|}{ FCPS/MRCP(MED) } & \multicolumn{3}{|c|}{ FCPS-1/MRCP-1(MED) } & \multicolumn{3}{|c|}{ MBBS/MD(MED) } & \multicolumn{3}{|c|}{ GPs } & \multicolumn{3}{|c|}{ Quacks } \\
\hline Stro & Mode & Dis & Stro & Mode & Dis & Stro & Mode & Dis & Stro & Mode & Dis & Stro & Mode & Dis \\
\hline ngly & rately & agreed & ngly & rately & agreed & ngly & rately & agreed & ngly & rately & agreed & ngly & rately & agreed \\
\hline Agre & Agre & & Agre & Agre & & Agre & Agre & & Agre & Agre & & & & \\
\hline ed & ed & & ed & ed & & ed & ed & & ed & ed & & & & \\
\hline 1 & 2 & 0 & 2 & 5 & 0 & 16 & 12 & 7 & 11 & 2 & 2 & 15 & 6 & 4 \\
\hline 3 & 0 & 0 & 7 & 0 & 0 & 30 & 1 & 4 & 13 & 0 & 2 & 11 & 10 & 4 \\
\hline 2 & 1 & 0 & 4 & 1 & 2 & 17 & 10 & 8 & 6 & 6 & 3 & 12 & 10 & 3 \\
\hline 0 & 3 & 0 & 1 & 6 & 0 & 17 & 13 & 5 & 10 & 3 & 2 & 14 & 8 & 3 \\
\hline 0 & 3 & 0 & 3 & 4 & 0 & 21 & 9 & 5 & 9 & 3 & 3 & 13 & 6 & 6 \\
\hline 3 & 0 & 0 & 6 & 0 & 1 & 25 & 3 & 7 & 12 & 1 & 2 & 14 & 6 & 5 \\
\hline \multicolumn{15}{|c|}{${ }^{*} \mathrm{MBBS} / \mathrm{MD}(\mathrm{MED})=$ Doctor who is working more than 3 years in the field of medicine. } \\
\hline \multicolumn{15}{|c|}{${ }^{* *} \mathrm{QUACK}=\mathrm{A}$ person who is doing practice as a doctor though he is not a qualified doctor } \\
\hline
\end{tabular}


From the $3^{\text {rd }}$ group $19.75 \%$ participants answered the 12 questions in whole as "Yes", 9.92\% answered as "No" and 5.33\% answered "Don't Know".

From the $4^{\text {th }}$ group $7.42 \%$ participants answered the 12 questions in whole as "Yes", 5.25\% answered as "No" and 2.33\% answered "Don't Know".

From the $5^{\text {th }}$ group $10.58 \%$ participants answered the 12 questions in whole as "Yes", $10.17 \%$ answered as "No" and 4.25\% answered "Don't Know" (Table 12).

\section{Qualification based striatum (Group 2)}

Total 149 participants were approached, out of which 85 answered the questionnaire. On the basis of qualification, this data is divided into different groups;

1. $\quad \mathrm{FCPS}(\mathrm{MED}) / \mathrm{MRCP}=3$

2. FCPS-1(MED)/MRCP- $1=7$

3. $*$ MBBS $/ \mathrm{MD}(\mathrm{MED})=35$

4. $\mathrm{GPs}=15$

5. ${ }^{* *} \mathrm{QUACKS}=25$

From the $1^{\text {st }}$ group $1.50 \%$ participants "Strongly Agreed", 1.50\% "Moderately Agreed" and 0\% "Disagreed".

From the $2^{\text {nd }}$ group 3.83\% participants "Strongly Agreed", 2.67\% "Moderately Agreed" and 0.5\% "Disagreed".

From the $3^{\text {rd }}$ group 21\% participants "Strongly Agreed", 8\% "Moderately agreed" and 6\% "Disagreed".

From the $4^{\text {th }}$ group $10.17 \%$ participants "Strongly Agreed", 2.50\% "Moderately agreed" and 2.33\% "Disagreed".

From the $5^{\text {th }}$ group $13.17 \%$ participants "Strongly Agreed", 7.67\% "Moderately agreed" and 4.17\% "Disagreed" (Table 13).

Table 13: Common infections prevalent in infants.

\begin{tabular}{|c|c|}
\hline S.No & Infections \\
\hline 1 & Diarrhoea \\
\hline 2 & Pharyngitis \\
\hline 3 & Pneumonia \\
\hline 4 & Otitis Media \\
\hline 5 & Sinusitis \\
\hline 6 & Urinary Tract Infection \\
\hline
\end{tabular}

other necessary information for prudent use of antibiotics

\section{All Participants}

i. Please share with us about three most common infections prevalent in infants? (Table 14)
Table 14: Frequently Used Antibiotics in Infants.

\begin{tabular}{|c|c|}
\hline S.No & Antibiotics \\
\hline 1 & Ceftazidime \\
\hline 2 & Amikacin \\
\hline 3 & Gentamicin \\
\hline 4 & Ampicillin \\
\hline 5 & Cefixime \\
\hline 6 & Ceftriaxone \\
\hline 7 & Amoxycillin \\
\hline 8 & Cefuroxime \\
\hline
\end{tabular}

ii. Please share three most frequently used antibiotics in infants? (Table 15)

Table 15: Calculate the dose of an Antibiotic in Infants.

\begin{tabular}{|c|c|}
\hline \multicolumn{2}{|c|}{ Body Weight } \\
\hline \multicolumn{2}{|c|}{$\begin{array}{l}\text { iii. Which criteria is considered best to calculate the dose } \\
\text { of an antibiotic in infants? (Table 16) }\end{array}$} \\
\hline S.No & Antibiotics \\
\hline 1 & Amoxycillin \\
\hline 2 & Cefuroxime \\
\hline 3 & Cefixime \\
\hline 4 & Ceftriaxone \\
\hline
\end{tabular}

iv. Please share your experience and tell us which broad spectrum antibiotic you think is safest in infants?

\section{Suggestions to Improve the Prudent Use of Antibiotics}

i. $\quad$ Proper investigations and diagnosis (Table 17)

Table 17: Proper Investigations and Diagnosis.

\section{PRESCIBERS AGREED TO THIS OUT OF 85}

ii. Improve antibiotics knowledge and awareness (Table 18)

Table 18: Improve antibiotics knowledge and awareness. 75 PRESCIBERS AGREED TO THIS OUT OF 85

iii. Rapid culture and sensitivity facility (Table 19)

Table 19: Rapid culture and sensitivity facility.

77 PRESCIBERS AGREED TO THIS OUT OF 85

iv. Evidence based use of antibiotics (Table 20)

Table 20: Evidence based use of antibiotics.

69 PRESCIBERS AGREED TO THIS OUT OF 85

v. Restrict over-the-counter sale of antibiotics (Table 21) 
Table 21: Restrict over-the-counter sale of antibiotics.

79 PRESCIBERS AGREED TO THIS OUT OF 85

vi. Crack down of Quacks (Table 22)

Table 22: Crack down of Quacks.

60 PRESCIBERS AGREED TO THIS OUT OF 85

vii. Ensure complete cure (Table 23).

Table 23: Ensure complete cure.

78 PRESCIBERS AGREED TO THIS OUT OF 85

viii. Improvement in sterilization in hospitals to reduce the nosocomial infections (Table 24).

Table 24: Improvement in sterilization in hospitals to reduce the nosocomial infections.

82 PRESCIBERS AGREED TO THIS OUT OF 85

ix. Use the Skills of clinical pharmacists (Table 25).

Table 25: Use the Skills of clinical pharmacists.

\section{PRESCIBERS AGREED TO THIS OUT OF 85}

x. No suggestion (Table 26).

Table 26: No Suggestion.

\section{PRESCIBERS GIVE NO SUGGESTION OUT OF 85}

\section{Discussion}

According to results obtained from the prescribers of City area and Semi-urban or Rural area (STRIATUM \# 1, Group 1, Area Based Striatum), the prescribers of City Area are more rational as compared to Semi-Urban or Rural Area regarding general antibiotic use.

According to the answers of the questions of (STRIATUM\#1, Group 2, Area Based Striatum), the prescribers of the city area are more rational as compared to the Semi-urban or rural area.

In the (STRIATUM \# 2, Group 1, Qualification Based Striatum), as we go from highly educated and experienced prescribers to less educated prescribers or layman, the antibiotic use become injudicious i-e, irrational.

In the (STRIATUM \# 2, Group 2, Qualification Based Striatum), same is the case as of group 1 answers, i.e., less educated prescribers and non-qualified doctors are using antibiotic irrationally than highly qualified specialist doctors.

The prescribers diagnose Diarrhoea, Pharyngitis and Pneumonia as most common infections prevalent in Infants. Besides these, according to some prescribers, Otitis media, Sinusitis and Urinary Tract Infections are also prevalent in Infants. The three most commonly used antibiotics in Infants are Ceftazidime, Amikacin and Ampicillin. Other antibiotics which are also used frequently to treat infection in Infants are Gentamicin, Cefixime, Amoxycillin, Ceftriaxone and Cefuroxime. Body Weight,is the best criteria for dose calculation in Infants [1].

Regarding safest broad spectrum antibiotic in infants, prescribers use Amoxycillin, Cefuroxime, Ceftriaxone and Cefixime. That is, they Consider penicillins and Cephalosporins to be safe in Infants. However, studies suggest that penicillins are safe for use in infants $[9,10]$ whereas, cephalosporins have severe side effects especially when used with calcium and also cause Kernicterus in newborns so should be used with caution in neonates especially when used in combination with calcium e.g, concomitant therapy of Ceftriaxone and Calcium is contraindicated in infants [11].

Some suggestions from prescribers were also asked regarding prudent use of antibiotics. According to them, proper investigation and diagnosis [12], improved antibiotic knowledge and awareness, rapid culture and sensitivity test, crack down of Quacks, reduction in the nosocomial infection by improving sterilization in the hospitals and by restricting the over-thecounter sales of the antibiotics are important factors for the judicious and safe use of the antibiotics.

\section{Conclusion}

It is clear from the above discussion that lack of true diagnosis, antibiotic resistance and purulent discharge are the major influential factors to prescribe broad spectrum antibiotics instead of narrow spectrum. Moreover, lack of an antibiogram facility, patient pressure/satisfaction and lack of rapid culture and sensitivity test facility, lack of proper investigation and diagnosis, also contributes to prescribe broad spectrum antibiotics where narrow spectrum antibiotics can be used. Is was also come into notice that antibiotics, which are a special group of medicine and must be handled with extreme care, are being used by quacks and LHVs, who are not expert to prescribe medicine, especially antibiotics. There must be evidence based use of antibiotics. Almost all the prescribers are convinced on the fact that there must be improved sterilization in the hospital to avoid nosocomial infections. This would extremely helpful in reducing the antibiotic usage and also antibiotic resistance in the hospitals and would also reduce the stay of the patient in the hospital and also the medication cost and others costs. Improved antibiotic knowledge and patient awareness, ensuring complete cure while using an antibiotic is also necessary for prudent use of antibiotics.

\section{References}

1. Katzung Pharmacology (2008) Chapter 43. Beta-Lactam Antibiotics \& Other Inhibitors of Cell Wall Synthesis. Mc Graw-Hill, USA, pp. 10361053.

2. Brunton LL, Lazo JS, Keith (2006) Goodman \& Gilman's the Pharmacological Basis of Therapeutics. (11 ${ }^{\text {th }}$ edn), Murray Media, North Miami Beach, FL, USA. 
3. Buetow SA, Sibbald B, Cantrill JA, Halliwell S (1997) Appropriateness in health care: application to prescribing. Soc Sci Med 45(2): 261-271.

4. ASM (1995) Report of the A.S.M. Task Force on Antibiotic Resistance. Antimicrob Agents Chemother 39(5 Suppl): 1-23.

5. Okeke NI, Lamikanra A, Edelman R (1999) Socioeconomic and behavioral factors leading to acquired bacterial resistance to antibiotics in developing countries. Emerg Infect Dis 5(1): 18-27.

6. Abosede OA (1984) Self-medication: an important aspect of primary healthcare. Soc Sci Med 19(7): 699-703.

7. Duong VD, Binns WB, Le VT (1997) Availability of antibiotics as overthe-counter drugs in pharmacies: A threat to public health in Vietnam. Trop Med Int Health 2(12): 1133-1139.
8. Memon K (2001) Use of drugs in Sind Province Pakistan primary health care facilities.

9. Briggs GG, Freeman RK, Yaffe SJ (2005) Drugs in Pregnancy \& Lactation. ( $7^{\text {th }}$ edn), Lippincott, USA.

10. Belliard CR, Sibille G (2007) Anaphylactoid shock or precipitation of calcium-ceftriaxone in a premature newborn. Arch Pediatr 14(2): 199200 .

11. Demirbas F, Gjermo PE, Preus HR (2006) Antibiotic prescribing practices among Norwegian dentists. Acta Odontol Scand 64(6): 335359.

12. Briggs GG (2008) Drugs in Pregnancy and Lactation ( $8^{\text {th }}$ edn). Lippincott Williams \& Wilkins, Philadelphia 2(2): 89.

\section{Your next submission with Juniper Publishers} will reach you the below assets

- Quality Editorial service

- Swift Peer Review

- Reprints availability

- E-prints Service

- Manuscript Podcast for convenient understanding

- Global attainment for your research

- Manuscript accessibility in different formats

( Pdf, E-pub, Full Text, Audio)

- Unceasing customer service

Track the below URL for one-step submission https://juniperpublishers.com/online-submission.php 